\title{
Productivity and recovery of forage fish under climate change and fishing: North Sea sandeel as a case study
}

Lindegren, Martin ; van Deurs, Mikael; MacKenzie, Brian; Worsøe Clausen, Lotte; Christensen, Asbjørn; Rindorf, Anna

\section{Published in:}

Fisheries Oceanography

Link to article, DOI:

10.1111/fog. 12246

Publication date:

2018

Document Version

Peer reviewed version

Link back to DTU Orbit

Citation (APA):

Lindegren, M., van Deurs, M., MacKenzie, B., Worsøe Clausen, L., Christensen, A., \& Rindorf, A. (2018).

Productivity and recovery of forage fish under climate change and fishing: North Sea sandeel as a case study. Fisheries Oceanography, 27(3), 212-221. https://doi.org/10.1111/fog.12246

\section{General rights}

Copyright and moral rights for the publications made accessible in the public portal are retained by the authors and/or other copyright owners and it is a condition of accessing publications that users recognise and abide by the legal requirements associated with these rights.

- Users may download and print one copy of any publication from the public portal for the purpose of private study or research.

- You may not further distribute the material or use it for any profit-making activity or commercial gain

- You may freely distribute the URL identifying the publication in the public portal 
1 Productivity and recovery of forage fish under climate change and fishing:

2 North Sea sandeel as a case study

3

4 MARTIN LINDEGREN ${ }^{1,2^{*}}$, MIKAEL VAN DEURS ${ }^{2}$, BRIAN R. MACKENZIE ${ }^{2}$, LOTTE $^{2}$

5 WORSOE CLAUSEN ${ }^{2,3}$, ASBJØRN CHRISTENSEN ${ }^{2}$, ANNA RINDORF $^{2}$

$6{ }^{1}$ Centre for Ocean Life, National Institute of Aquatic Resources, Technical University of Denmark,

7 Charlottenlund Castle, DK-2920 Charlottenlund, Denmark. ${ }^{2}$ National Institute of Aquatic

8 Resources, Technical University of Denmark, Charlottenlund Castle, DK-2920 Charlottenlund,

9 Denmark. ${ }^{3}$ ICES Secretariat, H. C. Andersens Boulevard 44-46, DK-1553 Copenhagen, Denmark

10 *Corresponding author: mli@aqua.dtu.dk

RUNNING HEAD: Productivity and recovery of forage fish 


\section{ABSTRACT}

21 Forage fish occupy a central position in marine food-webs worldwide by mediating the transfer of 22 energy and organic matter from lower to higher trophic levels. The lesser sandeel (Ammodytes 23 marinus) is one of the ecologically and economically most important forage fish species in the 24 North-east Atlantic, acting as a key prey for larger fish and sea birds, as well as supporting a large 25 commercial fishery. In this case study, we investigate the underlying factors affecting recruitment 26 and how these in turn affect productivity of the North Sea sandeel using long-term data and 27 modelling. Our results demonstrated how sandeel productivity in the central North Sea (Dogger 28 Bank) depends on a combination of external and internal regulatory factors, including fishing and 29 climate effects, as well as density dependence and food availability of the preferred zooplankton 30 prey (Calanus finmarchicus and Temora longicornis). Furthermore, our model scenarios suggest 31 that while fishing largely contributed to the abrupt stock decline during the late 1990s and the 32 following period of low biomass, a complete recovery of the stock to the highly productive levels of 33 the early 1980s would only be possible through changes in the surrounding ecosystem, involving 34 lower temperatures and improved feeding conditions. To that end, we stress the need for ecosystembased management accounting for multiple internal and external factors occurring within the broader context of the ecosystem in which forage fish species, such as sandeel, play an important and integral part.

KEY WORDS: population dynamics, recruitment, modelling, climate change, fisheries management 


\section{INTRODUCTION}

Forage fish occupy a central position in marine food-webs worldwide (Cury et al., 2000; Chekley et al., 2009). By feeding on zooplankton and acting as a primary prey for large fish, marine birds and mammals, these fish species effectively mediate the transfer and flow of energy and organic matter from lower to higher trophic levels in marine ecosystems. Furthermore, these small, fast growing and typically short-lived species usually show highly variable population dynamics, both in terms of individual growth and recruitment (Checkley et al., 2009; MacKenzie et al., 2012; Lindegren and Checkley 2013; Bartolino et al., 2014). Since only a few species dominate these mid-trophic levels, important ecosystem functions and services (including both supporting and provisioning services such as food for naturally occurring predators and for human consumption) are highly sensitive to changes in the abundances of these species (Cury et al., 2000; Engelhard et al., 2014; Lindegren et al., 2016). Therefore, understanding the underlying factors regulating their large-scale fluctuations and population dynamics is utterly important.

Several studies have demonstrated clear top-down fishing effects on forage fish, usually exemplified by the dramatic collapses of commercially important small pelagic fish stocks of herring, sardines and anchovies (e.g., Dragesund et al., 1980; Coetzee et al., 2008; Freon et al., 2008). In addition, bottom-up forcing, mediated through direct physiological responses to environmental factors or indirect responses to climate-driven changes in the composition and availability of zooplankton prey has been shown to underlie large-scale fluctuations of forage fish, such as the alternating dominance of sardines and anchovies in upwelling systems (Baumgartner et al., 1992; Schwartzlose et al., 1999; Alheit and Niquen 2004; van der Lingen et al., 2006; Checkley et al., 2017). Although many studies have identified single drivers, the potential synergy of multiple 
66 internal and external factors in regulating population dynamics of forage fish, as well as their 67 relative importance throughout ontogeny is a largely unresolved issue (Hjermann et al., 2004; Lindegren et al., 2011;2013). Given the ecological importance and high socio-economic value of forage fish worldwide, an ecosystem-based management approach, taking into consideration multiple external and internal regulating processes, is necessary to promote sustainable exploitation

of these important marine resources and the diverse set of higher trophic level predators they support (McLeod and Leslie 2009).

The lesser sandeel (Ammodytes marinus) is one of the ecologically and economically most important forage fish species in the North-east Atlantic, acting as the preferred prey for predatory fish, marine mammals and birds, as well as supporting a large and lucrative fishery (Furness 2002; Greenstreet et al., 2006; Engelhard et al., 2014; Dickey-Collas et al., 2014). The industrial sandeel fishery began in the 1960s, when it mainly targeted sandeel populations in the North Sea. At its peak in the 1990s this largely unregulated fishery was removing a sandeel biomass amounting to $\sim 1$ million tonnes per year. In the early 2000 s, the stock biomass declined rapidly and so did the landings and profitability of the fishery (Dickey-Collas et al., 2013; Engelhard et al., 2014; Fig. 1a, b). In order to promote stock recovery, the fishery has been under quota regulations for almost a decade, yet stock biomass has remained low and not returned to the productive levels of the 1980s (van Deurs et al., 2009; Lynam et al., 2013; Engelhard et al., 2014; ICES 2017). Lesser sandeel in the central North Sea spend most of the year buried within the bottom sediment (Wright et al., 2000; van Deurs et al., 2011). The growth period is confined to spring when they resurface and feed on copepods, such as the large Calanus sp. and the medium sized Temora longicornis (Macer 1966; van Deurs et al,. 2013, 2014). Although a large number of factors have been proposed as drivers of the population dynamics of sandeel, including biotic processes (Arnott and Ruxton 2002a; 
90 Frederiksen et al., 2007; Dickey-Collas et al., 2013; van Deurs et al., 2013; Eigaard et al., 2014), as

91 well as climate forcing and fishery effects (Berntsen et al., 1994; Arnott and Ruxton 2002b;

92 Frederiksen et al., 2007; van Deurs et al., 2009; Eliasen et al., 2011, van Deurs et al., 2014) the

93 ultimate mechanisms preventing stock recovery are largely unknown, let alone quantified. In this

94 study, we investigate the underlying factors regulating recruitment and productivity of sandeel in

95 the central North Sea (Dogger bank) and assess the productivity and recovery potential of the stock

96 under different climate and fishing scenarios using a coupled modelling approach. Understanding

97 the combination and potential synergy of these internal and external factors is a prerequisite for

98 development of ecosystem-based management practices necessary to promote sustainable

99 exploitation of sandeel and other marine living resources worldwide (McLeod and Leslie 2009).

100

101

102

\section{MATERIAL AND METHODS}

103

104

105

106

107

108

109

110

111

112

\subsection{Data availability}

A number of variables characterising the local physical conditions, as well as regional oceanatmospheric forcing, were collected (Table 1). The local climate conditions were represented by average sea surface temperatures (SST) at the Dogger Bank in each year and quarter, based on the Hadley centre observational data set available on a one-degree grid cell resolution (Fig. 1c), as well as mean annual sea bottom temperatures available from ICES (http://ecosystemdata.ices.dk/). In order to represent regional ocean-atmospheric forcing acting at larger spatial scales, we included annual averages of the North Atlantic Oscillation Index (NAO), representing the leading Empirical Orthogonal Function (EOF) of sea level pressure over the Atlantic sector $\left(20^{\circ}-80^{\circ} \mathrm{N}, 90^{\circ} \mathrm{W}-40^{\circ} \mathrm{E}\right)$. The number of recruits at age zero ("0-group"; R) and spawning stock biomass (SSB) estimates were derived from stock assessments for the years 1983-2015 of sandeel in the Dogger Bank (Fig. 
113 1a, b), i.e., representing sandeel assessment area 1 (ICES 2017; see also Fig. S1). To account for

114 density-dependent effects on sandeel recruitment (Arnott \& Ruxton 2002a), the number of one-year

115 old individuals was included. Finally, the abundances of the key zooplankton prey species Calanus

116 fincmarchicus and Temora longicornis (Fig. 1d) in the Dogger Bank area in each quarter were

117 available from the long-term monitoring of the Continuous Plankton Recorder (CPR; Batten et al.,

118 2003; Johns 2017).

119

120

\subsection{Statistical analysis and recruitment modelling}

121 Generalized Additive Models (GAMs; Hastie and Tibshirani, 1990; Wood 2006) were used to

122 examine the relationship between sandeel recruitment success (R/SSB) and the set of biotic and

123 abiotic variables chosen as possible predictors during model fitting and selection. The following

124 linearized Ricker formulations with log-transformed recruitment success estimates as responses

125 were used:

$126 \log (\mathrm{R} / \mathrm{SSB})_{\mathrm{t}}=a+s\left(\log \left(\mathrm{SSB}_{\mathrm{t}}\right)\right)+s\left(\log \left(\mathrm{N}_{\mathrm{t}}\right)\right)+s\left(\mathrm{~V}_{\mathrm{t}}\right)+\varepsilon$

127 where $a$ is the intercept, $s$ the thin plate smoothing function, SSB the spawning stock biomass, N1

128 the number of one-year olds, $\mathrm{V}$ a number of selected climate predictors potentially affecting sandeel

129 recruitment success (Table 1 ) and $\varepsilon$ the error term. Although the number of regression splines is

130 optimized (and penalized) by the generalized cross validation criterion (GCV), the degrees of

131 freedom of the spline smoother function $(s)$ was further constrained to three knots $(\mathrm{k}=3)$ to allow for

132 potential nonlinearities, but restrict flexibility during model fitting. Finally, we applied a model

133 reduction routine based on the GCV and partial $F$-tests to find the best possible set of predictors. To

134 limit the number of candidate models and avoid false positive results arising from multiple model 
135 testing we restricted the set of models to include covariates averaged for the same quarter or as 136 annual means (Table S2). In addition, we performed a cross validation analysis by fitting the final 137 model to a randomly selected subset of the data (Picard and Cook 1984), i.e., amounting to $75 \%$ of 138 the observations, and then assessing the predictive accuracy of the models by comparing the 139 observed values with the predicted recruitment estimates for the remaining subset. The cross140 validation analysis was repeated 1000 times (i.e., with a new set of random and serially independent 141 draws each time) in order to assess the range of uncertainty associated with the predictions.

\subsection{Age-structured model}

144

145

146

147

148

149

150

151

152

153

154

155

156

In order to simulate stock dynamics under different climate and fishing scenarios we applied a standard age-structured cohort model based on available information and parameters derived from recent stock assessments (ICES 2017). The simulated population dynamics are represented by numbers-at-age $(\mathrm{N})$ distributed among 5 age classes (from 0 to $4+$ ), where the so-called plus group includes all fish 4 years and older. The following formulation was used:

$\mathrm{N}_{\mathrm{a}+1, \mathrm{t}+1}=\mathrm{N}_{\mathrm{a}+1} e^{-\left(\mathrm{F}_{\mathrm{a}+1}+\mathrm{M}_{\mathrm{a}+1}\right)}$

where $\mathrm{N}_{\mathrm{a}, \mathrm{t}}$ are number-at-age a in year $\mathrm{t}, \mathrm{F}_{\mathrm{a}, \mathrm{t}}$ and $\mathrm{M}_{\mathrm{a}, \mathrm{t}}$ the fishing mortality and the natural mortality at age a in year $t$, respectively. The simulations were performed by estimating R/SSB based on the final S-R model (Eg. 1; Table 3) and the observed values of each covariate in a given year, where SSB was estimated as the sum of the adult population given by the proportion of mature fish in each age and year and their corresponding numbers and mean weight-at-age (ICES 2017). In addition, a stochastic element was included by adding Gaussian noise (e; resampled randomly from the residuals of the S-R models) to account for unexplained sources of recruitment variability. After 
157 having accounted for intrinsic processes (i.e., growth, maturation, and natural mortality), as well as

158 external factors (i.e., fishing mortality) in the age-structured cohort models, the forward simulation

159 loop is reiterated by estimating R/SSB in the following year. Similar to the available stock

160 assessment model the simulation model applies half-year time steps, where recruitment occurs from

161 the $1^{\text {st }}$ to the $2^{\text {nd }}$ part of the year.

162

163

\subsection{Model simulations and scenario testing}

164

165

166

167

168

169

170

171

172 observed peak in 1990; Fig. 1d); (iv) and all treatments above (i-iii) together. Furthermore, we

173 performed multiple stochastic simulations (i.e., by randomly resampling and reintroducing residuals

174 from the final GAM model) and estimated the probability of collapse as the percentage of

175 simulations in which SSB falls below the agreed stock reference point below which recruitment is

176 impaired $\left(\mathrm{B}_{\lim }=160000\right.$ tonnes) for each combination of SST (i.e., ranging from 0 to $+2{ }^{\circ} \mathrm{C}$ relative

177 to mean SST) and fishing, given by a scaling factor on mean fishing mortalities-at-age (F) ranging

178 from 0 to 2 (i.e., representing a fishing closure and doubling of mean Fs, respectively). Probabilities

179 were based on consecutive $\mathrm{SSB}$ values residing below $\mathrm{B}_{\mathrm{lim}}$ for a period longer than one generation 
180 (i.e., amounting to 4 years). The simulations were initialized at the estimated numbers at age in 1812015 run for 30 years, and replicated 1000 times for each combination of $\Delta$ SST and F multipliers.

182 While observed SST values were used for model fitting and validation, surrogate time series of SST

183 were used as input during simulations. Since marine climate is generally positively autocorrelated

184 (Steele and Henderson 1984), we generated "red-shifted" noise accurately resembling the natural

185 variability of the observed SST time series by allowing the simulated SST time series to fluctuate

186 with the same mean, variance and degree of first-year autocorrelation as the observations

187 (Lindegren et al., 2010). The abundances of $C$. finmarchicus and T. longicornis were introduced in

188 the S-R model by stochastic resampling of observed values in each year due to the lack of a clear

189 auto-correlated signal. All statistical analyses were conducted using the R software, version 2.15.1

190 (www.r-project.org).

191

192 3. RESULTS

193 3.1. Drivers of recruitment success

194 After model fitting and selection the set of covariates retained within the final GAM included

195 spawning stock biomass (SSB), the number of one-year old sandeel (N1), spring sea surface

196 temperature ( $2^{\text {nd }}$ quarter) and spring abundances of both C. finmarchicus and T. longicornis (Table

197 2; Table S2). Although fitting on variables averaged during winter ( $1^{\text {st }}$ quarter $)$ yielded a slightly

198 lower GCV (Table S2), the resulting model included a spurious and ecologically unrealistic

199 negative effect of prey availability (T. longicornis) on recruitment success (Fig. S2). The chosen

200 model, including covariates averaged over spring instead, demonstrated low GCV and a high degree

201 of explained deviance overall (75.2\%). The final relationships between recruitment success,

202 spawning stock biomass (SSB) and the number of one-year old sandeel (N1) were represented by 
203 non-linear or linearly decreasing functions, respectively (Fig. 2a, b), where in the former case the

204 negative effect on recruitment success is exacerbated at higher values of $\log (\mathrm{SSB})$. The functional

205 relationship between recruitment success and SST was best described by a negative linear

206 relationship (Fig. 2c), while the effect of C. finmarchicus and T. longicornis were linear and

207 positive (Fig. 2d, e). The final model explains the long-term dynamics and inter-annual variability

208 in recruitment success and hindcasted SSB (based on the age-structured model) well throughout the

209 period (Fig. 3a, b). Furthermore, the cross-validation routine demonstrated a high degree of

210 explained deviance for models fitted to a random and serially independent subset of the data, as

211 well as accuracy in predicting the remaining data (Fig. 4a). In addition, the explained deviance and

212 significance ( $\mathrm{p}$-values) of the model terms remained high when successively fitted and annually

213 updated with data from 1997 to 2015 (Fig. 4b). Model residuals were normally distributed and

214 temporally uncorrelated for recruitment and recruitment success (Fig. S3). As a complement to the

215 GAM approach we provide a number of alternative model formulations based on standard Ricker

216 models and generalized linear models including polynomial terms to account for non-linear

217 interactions (Table S2). While the GAM formulation demonstrates the highest degree of explained

218 deviance, the alternative model formulations demonstrate that the explanatory variables identified in

219 the GAM approach contribute significantly to the prediction of recruitment and recruitment success

220 independent of model choice. This supports the robustness of our findings and additionally provides

221 parameterized models for future management applications.

222

223 3.2. Testing the relative importance of drivers through scenario simulations

224 The hindcast model simulations used to evaluate the relative importance of the various factors

225 affecting sandeel recruitment and survival showed that the scenario based on reduced fishing 
226 mortalities lead to a pronounced improvement in stock status relative to the control simulation with

227 SSB values rising above $B_{\text {lim }}$ throughout most of the period (Fig. 5a). The scenario of reduced SST

228 demonstrates a more moderate improvement in SSB compared to the control but show SSB values

229 above $\mathrm{B}_{\mathrm{lim}}$ in the early and late 2000 s. The scenario introducing recurring high abundances in $C$.

230 finmarchicus shows a rather minor response. Interestingly, the combined scenario introducing all

231 "treatments" shows considerably higher SSB values well above $\mathrm{B}_{\text {lim. }}$. Finally, the model simulations

232 of sandeel dynamics under different combinations of SST and exploitation illustrate a strong

233 dependence on both factors with a high probability of collapse at high levels of F and SST (Fig. 5b).

\section{DISCUSSION}

236 In this study we have demonstrated how sandeel productivity and the potential for stock recovery in

237 the Dogger Bank area of the North Sea depend on a combination of internal density-dependent

238 processes and external environmentally-driven factors. Among the external factors considered in

239 this study, SST in spring explained a large part of recruitment variability and demonstrated a clear

240 negative relationship. Consequently, the pronounced long-term increase and unprecedented high

241 SST values since the early 2000s can partly explain the poor recruitment success and lack of

242 recovery during recent decades. Furthermore, we show a strong negative relationship between the

243 abundance of one-year old sandeel and recruitment success (settling of young of the year fish)

244 indicating pronounced density-dependent regulation, likely acting through food or habitat

245 competition. The dependence on food availability is supported by the positive effect of $C$.

246 finmarchicus and T. longicornis on recruitment success, illustrated by the close correspondence

247 between peaks in prey abundance with years of high recruitment success. The set of drivers

248 identified in our study largely corresponds with previous work on sandeel recruitment (Arnott and 
249 Ruxton 2002; van Deurs et al., 2009). This indicates that environmental correlates in relation to

250 this particular stock appear to be exceptionally robust over time, even when performed on

251 significantly extended time series and despite a common tendency for published recruitment-

252 environment correlations to fail when verified upon retest (Myers 1998). Based on this

253 consistency and the strong support for the drivers and relationships identified we used a scenario-

254 based modelling approach for assessing how different climate regimes and fishing pressures interact

255 to determine stock productivity and the potential for stock recovery (Lehodey et al., 2006).

256 However, before discussing these scenarios, we address the causality between the set of drivers and

257 their associated effects on recruitment and stock productivity.

First of all, increasing water temperature affects fish metabolism, resulting in higher growth rates, if food is not a limiting factor and/or if the temperature is not already near the thermal tolerance limit of the species (Pörtner 2002). In contrast, if food is limiting, growth will decline and the fish may starve because of increased energetic costs of metabolism. This effect will depend on temperature as a specific amount of food may be sufficient at low temperatures but cause decreased growth at high temperatures. Lesser sandeel inhabiting the Dogger area in the North Sea, are not living on the southern or the northern limit of the distribution range of this species (Jensen et al., 2010; Fishbase 2016). Consequently, the temperatures they experience do not appear to be at, or close to, its

267 thermal limits. However, the combination of increasing metabolic demands, driven by increasing 268 temperatures, together with stable or decreasing prey availability (i.e., abundance of $C$.

finmarchicus and T. longicornis) suggest that food limitation can limit recruitment success and

270 stock recovery. This is particularly important during late winter and spring as this period covers the

271 larval phase (Wright and Bailey 1996). Increasing temperatures lead to increasing energy demands

272 potentially affecting developmental rate of the larvae (Pankhurst and Munday 2011). Furthermore, 
273 in late winter and early spring food is exceptionally scarce and eggs and nauplii of C. finmarchicus, 274 advected into the North Sea from the Atlantic continental shelf, may represent a vital resource for 275 the newly hatched larvae in this area of the North Sea (Arnott and Ruxton 2002; Richardson et al., 276 2011). In addition, T. longicornis and other medium sized calanoid copepods often serve as other 277 important prey in this area (Macer 1966; van Deurs et al. 2014). These copepod species become 278 abundant in late spring, around the time of sandeel metamorphosis, which is another critical life 279 stage of sandeel (Wright and Bailey 1996). Hence, delayed or suppressed copepod production 280 during this period may cause starvation and consequently limit survival and year class strength. 281 Although T. longicornis is far more abundant than C. fincmarchicus in late spring (Pitois and Fox 282 2006), this less abundant prey species may still be important, owing to its larger size and higher fat 283 content (van Deurs et al. 2014).

While these mechanisms stress a strong link between stock productivity and the environment, the long-term increase in SST and decline of C. finmarchicus and T. longicornis in the North Sea should be understood within the broader context of large-scale ecosystem changes acting across the North East Atlantic (Beaugrand et al., 2004; Möllmann et al., 2009; Lindegren et al., 2012). These abrupt changes, often referred to as regime shifts, involve a number of additional factors potentially affecting the population dynamics of sandeel in the North Sea, such as an increasing number of 291 competing forage fish species and predators on sandeel larvae and juveniles (Raab et al., 2012;

292 Petitgas et al., 2012; Engelhard et al., 2014) and pronounced shifts in the phyto- and zooplankton 293 community composition (Reid et al., 1998; Beaugrand 2004; Beare et al., 2004; Jansen and 294 Gislason 2011). These effects are exacerbated by the resident nature of sandeel, which due to its 295 strong association to a well-defined and patchily distributed habitat (Wright et al., 2000; Jensen et 
296 al., 2011) cannot change distribution and take advantage of better conditions elsewhere (Helaouët 297 and Beaugrand 2007).

After demonstrating the importance of both internal, density-dependent mechanisms and external, climate-driven factors, including temperature and food availability in regulating sandeel recruitment (Berntsen et al., 1994; Arnott and Ruxton 2002a; Frederiksen et al., 2007; Dickey-Collas et al., 2013; van Deurs et al., 2009; 2013; 2014; Eigaard et al., 2014), the question remains to what extent past changes in these drivers explain the poor productivity and virtual lack of recovery in recent assessing the relative importance of these factors, particularly in relation to commercial fishing. Our results show that fishing largely contributed to the abrupt stock decline during the late 1990s and the following period of low biomass, especially given the extreme fishing mortalities experienced during this period (i.e. mean $F=1.2$ between 1999 to 2004; Fig. 1b). However, although reducing F to the currently lower levels would likely have maintained the stock biomass above ecologically safe levels (Fig. 5a) a complete recovery of the stock to the highly productive levels of the early 1980s would not have been possible, despite the lower level of exploitation. This highlights that factors besides fishing also contributed to the stock decline and to maintaining the stock in a state of poor productivity. We argue that these factors can be explained by the pronounced increase in SST, the concurrent decline in food availability, as well as the recent increase in natural mortality, especially through predation from mackerel. Whether recruitment and recovery of other sandeel stocks in the area are influenced or limited by the same set of drivers and processes is unclear and merit further attention. However, the joint dependence of recruitment and survival on fishing and environmental factors, including both abiotic and biotic processes, has been shown for several commercially important forage fish species (Freon et al., 2008; Lindegren et al., 2011, 2013; 
320 Checkley et al., 2017), as well as for large predatory fish stocks worldwide, notably cod (Lindegren

321 et al., 2009; Gårdmark et al., 2013; Pershing et al., 2015). This supports the generality of our

322 findings and illustrates the need to adopt a more holistic ecosystem-based approach to fisheries

323 management, accounting for multiple ecological and physical factors to promote sustainable

324 exploitation of our living marine resources (MacLeod and Leslie 2009; Long et al., 2015). Despite a

325 growing body of research on the effect of climate and biotic interactions on fish population

326 dynamics, only a very limited number of fish stocks worldwide are currently accounting for these

327 issues in tactical management (Skern-Mauritzen et al., 2015). To that end, we stress the need for

328 ecosystem-based management accounting for multiple internal and external factors occurring within

329 the broader context of the ecosystem, in which forage fish species, such as sandeel, play an

330 important and integral part.

331

332 ACKNOWLEDGEMENTS

333 The contributions by MvD and BRM in this investigation were supported in part by the COFASP

334 ERA-NET partners, which has received funding from the European Union's Seventh Framework

335 Programme for research, technological development and demonstration under grant agreement no.

336321553 (GOFORIT project), and by the national funding agency of Denmark (Innovationsfonden).

337 MvD was also supported by Management of North Sea sandeel in the years ahead (33113-B-15-002

338 European Fisheries and Maritime Fund). We also want thank SAHFOS for providing CPR-data and

339 two anonymous reviewers for their insightful and constructive comments.

340

341

342 


\section{REFERENCES}

344 Alheit, J. and Niquen, M. (2004) Regime shifts in the Humboldt Current ecosystem. Progress in

345 Oceanography 60:201-222.

346 Arnott, S. A., Ruxton, G. D., and Poloczanska, E. S. (2002a) Stochastic dynamic population model

347 of North Sea sandeels, and its application to precautionary management procedures. Marine

348 Ecology Progress Series 235:223-234.

349 Arnott, S. A. and Ruxton, G. D. (2002b) Sandeel recruitment in the North Sea: demographic,

350 climatic and trophic effects. Marine Ecology Progress Series 238:199-210.

351 Bartolino, V., Margonski, P., Lindegren, M., Linderholm, H., Cardinale, M., Rayner, D.,

352 Wennhage, H., Casini, M. (2014) Predicting fish stock dynamics under climate change: Baltic

353 herring as a case study. Fisheries Oceanography 23:258-269.

354 Batten, S.D., Clarke, R., Flinkman, J., Hays, G., John, E., John, A.W.G., Jonas, T.D., Lindley, J.A.,

355 Stevens, D., and Walne, A. (2003) CPR sampling: the technical background, materials and methods,

356 and issues of consistency and comparability. Progress in Oceanography 58:193-215.

357 Engelhard, G. H., Peck, M. A., Rindorf, A., Baumgartner, T., Soutar, A., and Ferreira-Bartrina, V.

358 (1992) Reconstruction of the history of Pacific sardine and northern anchovy populations over the

359 past two millennia from sediments of the Santa Barbara basin. CalCOFI Rep. 33:24-40.

360 Berntsen, J., Skagen, D. W., and Svendsen, E. (1994). Modelling the transport of particles in the

361 North Sea with reference to sandeel larvae. Fisheries Oceanography 3:81-91. 
362 Beare, D., Burns, F., Jones, E., Peach, K., Portilla, E., Greig, T., ... and Reid, D. (2004) An increase

363 in the abundance of anchovies and sardines in the north-western North Sea since 1995. Global

364 Change Biology 10:1209-1213.

365 Beaugrand, G. (2004) The North Sea regime shift: evidence, causes, mechanisms and

366 consequences. Progress in Oceanography 60:245-262.

367 Coetzee, J. C., van der Lingen, C. D., Hutchings, L., and Fairweather, T. P. (2008) Has the fishery

368 contributed to a major shift in the distribution of South African sardine? ICES Journal of Marine

369 Science 65:1676-1688.

370 Checkley, D.M., Alheit, J., and Oozeki, Y. (Editors) (2009) Climate change and small pelagic fish.

371 Cambridge University Press, Cambridge.

372 Checkley, D.M., Asch, R., Rykaczewski, R. (2017). Climate, Anchovy, and Sardine. Annual Review 373 of Marine Science 9:469-93.

374 Cury, P., Bakun, A., Crawford, R.J.M., Jarre, A., Quiñones, R.A., Shannon, L.J., and Verheye, 375 H.M. (2000) Small pelagics in upwelling systems: patterns of interaction and structural changes in 376 “wasp-waist” ecosystems. ICES J. Mar. Syst. 57:603-618.

377 Dickey-Collas, M., Engelhard, G. H., Rindorf, A., Raab, K., Smout, S., Aarts, G, Garthe, S. (2013)

378 Ecosystem-based management objectives for the North Sea: riding the forage fish

379 rollercoaster. ICES Journal of Marine Science 71:128-142.

380 Dragesund O., Hamre J., and Ulltang Ø (1980) Biology and population dynamics of the Norwegian

381 spring-spawning herring. Rapports et Procès-Verbaux des Réunions du Conseil International pour 382 l'Exploration de la Mer 177:43-71. 
383 Eigaard, O. R., Deurs, M. V., Behrens, J., Bekkevold, D., Brander, K., Plambech, M., and

384 Mosegaard, H. (2014) Prey or predator-expanding the food web role of sandeel (Ammodytes

385 marinus). Marine Ecology Progress Series 516:267-273.

386 Eliasen, K., Reinert, J., Gaard, E., Hansen, B., Jacobsen, J. A., Grønkjær, P., and Christensen, J. T.

387 (2011) Sandeel as a link between primary production and higher trophic levels on the Faroe

388 shelf. Marine Ecology Progress Series 438:185-194.

389 Engelhard, G. H., Peck, M. A., Rindorf, A., Smout, S. C., van Deurs, M., Raab, K., and Brunel, T.

390 (2014) Forage fish, their fisheries, and their predators: who drives whom? ICES Journal of Marine

391 Science 71: 90-104.

392 Fishbase (2016) http://www.aquamaps.org/receive.php?type of map=regular

393 Frederiksen, M., Furness, R. W., and Wanless, S. (2007) Regional variation in the role of bottom-up

394 and top-down processes in controlling sandeel abundance in the North Sea. Marine Ecology

395 Progress Series 337:279-286.

396 Fréon, P., Bouchon, M., Mullon, C., García, C., and Ñiquen, M. (2008) Interdecadal variability of

397 anchoveta abundance and overcapacity of the fishery in Peru. Prog. Oceanogr. 79: 401-412.

398 Furness, R. W., \& Tasker, M. L. (2000) Seabird-fishery interactions: quantifying the sensitivity of

399 seabirds to reductions in sandeel abundance, and identification of key areas for sensitive seabirds in

400 the North Sea. Marine Ecology Progress Series 202:253-264.

401 Greenstreet, S. P., Armstrong, E., Mosegaard, H., Jensen, H., Gibb, I. M., Fraser, H. M. and

402 Sharples, J. (2006) Variation in the abundance of sandeels Ammodytes marinus off southeast

403 Scotland: an evaluation of area-closure fisheries management and stock abundance assessment

404 methods. ICES Journal of Marine Science 63:1530-1550. 
405 Gårdmark A., Lindegren, M., Neuenfeldt, S., Blenckner, T., Heikinheimo, O., Müller-Karulis, B., 406 Niiranen, S., Tomczak, M., Aro, E., Wikström, A., Möllmann, C. (2013). Biological ensemble 407 modelling to evaluate potential futures of living marine resources. Ecological Applications, 23:742408754.

Hastie, T., and Tibshirani, R. (1990) Generalized additive models. Chapman and Hall, London.

410 Helaouët, P., and Beaugrand, G. (2007) Macroecology of Calanus finmarchicus and C.

411 helgolandicus in the North Atlantic Ocean and adjacent seas. Marine Ecology Progress

412 Series 345:147-165.

413 Hjermann, D.O., Ottersen, G., and Stenseth, N.C. (2004) Competition among fishermen and fish 414 causes the collapse of Barents Sea capelin. Proc. Natl. Acad. Sci. U.S.A. 101:11679-11684.

415 ICES (2017) Report of the Benchmark on Sandeel (WKSand 2016), 31 October - 4 November 416 2016, Bergen, Norway. ICES CM 2016/ACOM:33. 301pp.

417 Jansen, T., and Gislason, H. (2011) Temperature affects the timing of spawning and migration of 418 North Sea mackerel. Continental Shelf Research 31:64-72.

419 Jensen, H., Rindorf, A., Wright, P. J., and Mosegaard, H. (2010) Inferring the location and scale of 420 mixing between habitat areas of lesser sandeel through information from the fishery. ICES Journal 421 of Marine Science 68:43-51.

422 Jónasdóttir, S. H., and Koski, M. (2011) Biological processes in the North Sea: comparison of 423 Calanus helgolandicus and Calanus finmarchicus vertical distribution and production. Journal of 424 Plankton Research 33:85-103. 
425 Lehodey, P., Alheit, J., Barange, M., Baumgartner, T., Beaugrand, G., Drinkwater, K., and Roy, C.

426 (2006) Climate variability, fish, and fisheries. Journal of Climate 19:5009-5030.

427 Lindegren M., C. Möllmann, A. Nielsen, K. Brander, B. R. MacKenzie, and Stenseth N. C. (2010)

428 Ecological forecasting under climate change: the case of Baltic cod. Proceedings of the Royal

429 Society B-Biological Sciences 277:2121-2130.

430 Lindegren, M., Östman, Ö., and Gårdmark, A. (2011) Interacting trophic forcing and the population 431 dynamics of herring. Ecology 92:1407-1413.

432 Lindegren M., Blenckner T., and Stenseth N. C. (2012) Nutrient reduction and climate change cause 433 a potential shift from pelagic to benthic pathways in a eutrophic marine ecosystem. Global Change 434 Biology 18:3491-3503.

435 Lindegren, M., and D.M. Checkley, Jr. (2013) Temperature dependence of Pacific sardine

436 (Sardinops sagax) recruitment in the California Current revisited and revised. Canadian Journal of 437 Fisheries and Aquatic Sciences 52:566-577.

438 Lindegren, M., Checkley Jr. D. M., Rouyer T., MacCall A. D., and Stenseth N. C. (2013) Climate, 439 fishing, and fluctuations of sardine and anchovy in the California Current. Proceedings of the $440 \quad$ National Academy of Sciences of the United States of America 110:13672-13677.

441 Lindegren, M., Checkley, D.M., Jr., Ohman, M.D., Koslow, A., Goericke, R. (2016). Resilience and 442 Stability of a Pelagic Marine Ecosystem. Proceedings of the Royal Society B-Biological Sciences $443 \quad 283: 20151931$.

444 Long, R.D., Charles, A., Stephenson, R.L. (2015) Key principles of marine ecosystem-based 445 management. Marine Policy 57:53-60. 
446 Lynam, C. P., Halliday, N. C., Höffle, H., Wright, P. J., van Damme, C. J., Edwards, M., and Pitois, 447 S. G. (2013) Spatial patterns and trends in abundance of larval sandeels in the North Sea: 1950 448 2005. ICES Journal of Marine Science 70:540-553.

449 Macer, C. T. (1966) Sandeels (Ammodytidae) in the south-western North Sea: Their biology and 450 fishery. MAFF Fishery Invest, London ser. 1-55 pp.MacKenzie, B.R., Meier, H.E.M., Lindegren, 451 M., Neuenfeldt, S., Eero, M., Blenckner, T., Tomczak, M.T., and Niiranen, S. (2012) Impact of 452 climate change on fish population dynamics in the Baltic Sea: A dynamical downscaling 453 investigation. Ambio 41: 626-636.

454 McLeod, K. and Leslie H. (2009) Ecosystem-based management for the oceans. Island Press, 455 Washington, D.C., USA.

456 Möllmann C., Diekmann R., Müller-Karulis B., Kornilovs G., Plikshs M., and Axe P. (2009) 457 Reorganization of a large marine ecosystem due to atmospheric and anthropogenic pressure: a 458 discontinuous regime shift in the Central Baltic Sea. Glob Change Biol 15:1377-1399.

459 Myers, R. A. (1998) When do environment-recruitment correlations work?. Reviews in Fish 460 Biology and Fisheries 8: 285-305."

461 Pankhurst, N. W., and Munday, P. L. (2011) Effects of climate change on fish reproduction and 462 early life history stages. Marine and Freshwater Research 62:1015-1026.

463 Picard, R.R., and Cook, R.D. (1984) Cross-validation of regression models. J. Am. Stat. Assoc. $464 \quad 79: 575-583$.

465 Pershing, A. J., et al. (2015). Slow adaptation in the face of rapid warming leads to collapse of the 466 Gulf of Maine cod fishery. Science 350: 809-812. 
467 Petitgas, P., Alheit, J., Peck, M. A., Raab, K., Irigoien, X., Huret, M., ... and Dickey-Collas, M.

468 (2012) Anchovy population expansion in the North Sea. Marine Ecology-progress Series 444:1-13.

469 Pitois, S. G., and Fox, C. J. (2006) Long-term changes in zooplankton biomass concentration and 470 mean size over the Northwest European shelf inferred from Continuous Plankton Recorder data.

471 ICES Journal of Marine Science 63: 785-798.

472 Pörtner, H.O. (2002) Climate variations and the physiological basis of temperature dependent 473 biogeography: Systemic to molecular hierarchy of thermal tolerance in animals. Comparative 474 Biochemistry and Physiology - A Molecular and Integrative Physiology 132:739-761.

475 Raab, K., Nagelkerke, L. A. J., Boerée, C., Rijnsdorp, A. D., Temming, A., and Dickey-Collas, M. 476 (2012) Dietary overlap between the potential competitors herring, sprat and anchovy in the North 477 Sea. Marine Ecology Progress Series 470:101-111.

478 Reid, P. C., Edwards, M., Hunt, H. G., and Warner, A. J. (1998) Phytoplankton change in the North 479 Atlantic. Nature 391:546-546.

480 Richardson, K., Jónasdóttir, S. H., Hay, S. J., and Christoffersen, A. (1999) Calanus finmarchicus

481 egg production and food availability in the Faroe-Shetland Channel and northern North Sea:

482 October-March. Fisheries Oceanography 8:153-162.

483 Schwartzlose, R.A., Alheit, J., Bakun, A., Baumgartner, T.R., Cloete, R., Crawford, R.J.M., 484 Fletcher, W.J., Green-Ruiz, Y., Hagen, E., Kawasaki, T., Lluch-Belda, D., Lluch-Cota, S.E., 485 Maccall, A.D., Matsuura, Y., Nevarez-Martinez, M.O., Parrish, R.H., Roy, C., Serra, R., Shust, 486 K.V., Ward, M.N., and Zuzunaga, J.Z. (1999) Worldwide large-scale fluctuations of sardine and 487 anchovy populations. S. Afr. J. Mar. Sci. 21:289-347. 
488 Skern-Mauritzen, M., Ottersen, G., Handegard, N. O., Huse, G., Dingsør, G. E., Stenseth, N. C. and 489 Kjesbu, O. S. (2016) Ecosystem processes are rarely included in tactical fisheries management. Fish 490 and Fisheries 17: 165-175.

491 Steele, J. H. and Henderson, E. W. (1984) Modelling long-term fluctuations in fish stocks. Science $492 \quad 224: 985-987$.

493 Johns D. (2017) Monthly averaged zooplankton data for sandeel management area $11958-2015$ as 494 recorded by the Continuous Plankton recorder, Sir Alister Hardy Foundation for Ocean Science. 495 Plymouth. [25/05/2017] DOI is $10.7487 / 2017.178 .1 .1061$.

496 Van der Lingen C.D., Hutchings L., and Field J.G. (2006) Comparative trophodynamics of anchovy 497 Engraulis encrasicolus and sardine Sardinops sagax in the southern Benguela: Are species 498 alternations between small pelagic fish trophodynamically mediated? Afr J Mar Sci 28:465-477.

499 Van Deurs, M., van Hal, R., Tomczak, M. T., Jónasdóttir, S. H., and Dolmer, P. (2009).

500 Recruitment of lesser sandeel Ammodytes marinus in relation to density dependence and 501 zooplankton composition. Marine ecology progress series 381:249-258.

502 Van Deurs, M., Hartvig, M., and Steffensen, J. F. (2011) Critical threshold size for overwintering 503 sandeels (Ammodytes marinus). Marine biology 158:2755-2764.

504 Van Deurs, M., Koski, M., and Rindorf, A. (2014) Does copepod size determine food consumption 505 of particulate feeding fish?. ICES Journal of Marine Science 71:35-43.

506 Van Deurs, M., Jørgensen, C., and Fiksen, Ø. (2015) Effects of copepod size on fish growth: a 507 model based on data for North Sea sandeel. Marine Ecology Progress Series 520:235-243. 
508 Van Deurs, M., Christensen, A., and Rindorf, A. (2013) Patchy zooplankton grazing and high

509 energy conversion efficiency: ecological implications of sandeel behavior and strategy. Marine

510 Ecology-Progress Series 487:123-133.

511 Wood, S.N. (2006) Generalized additive models. An introduction to R. Chapman \& Hall/CRC, 512 Boca Raton.

513 Wright, P. J., and Bailey, M. C. (1996) Timing of hatching in Ammodytes marinus from Shetland 514 waters and its significance to early growth and survivorship. Marine Biology 126:143-152.

515 Wright, P. J., Jensen, H., and Tuck, I. (2000) The influence of sediment type on the distribution of 516 the lesser sandeel, Ammodytes marinus. Journal of Sea Research 44:243-256.

517 Wright, P. J., Jensen, H., and Tuck, I. (2000) The influence of sediment type on the distribution of 518 the lesser sandeel, Ammodytes marinus. Journal of Sea Research 44: 243-256. 519 


\section{TABLES}

Table 1. Information about the abiotic and biotic covariates used during model fitting with regards to spatial and temporal coverage, as well as the source of datae.

\begin{tabular}{llll} 
Variable & Month & Area & Data source \\
\hline SSTQ1 & Jan-March & Dogger Bank & http://www.metoffice.gov.uk/hadobs/hadisst/data/download.html \\
SSTQ2 & April-June & Dogger Bank & http://www.metoffice.gov.uk/hadobs/hadisst/data/download.html \\
SSTQ3 & July-Sept & Dogger Bank & http://www.metoffice.gov.uk/hadobs/hadisst/data/download.html \\
SSTQ4 & Oct-Dec & Dogger Bank & http://www.metoffice.gov.uk/hadobs/hadisst/data/download.html \\
SST Annual & Jan-Dec & Dogger Bank & http://www.metoffice.gov.uk/hadobs/hadisst/data/download.html \\
SBT Annual & Jan-Dec & North Sea & http://ecosystemdata.ices.dk/ \\
NAO Annual & Jan-Dec & North Atlantic & https://climatedataguide.ucar.edu/climate-data/hurrell-north-atlantic-oscillation-nao-index-pc-based \\
C.finmarchicus & Jan-Dec & Dogger Bank & Johns (2017) \\
T.longicornis & Jan-Dec & Dogger Bank & Johns (2017
\end{tabular}


Table 2. Summary statistics of parametric coefficients and smooth terms for the final stockrecruitment model for North Sea sandeel.
A. Intercept

Estimate $\quad \mathrm{SE} \quad \mathrm{t}$-value $\mathrm{p}$-value

$\begin{array}{llll}-0.52 & 0.1 & -5.34 & <0.001 * * *\end{array}$

B. Smooth terms

$\begin{array}{lllll}\text { Predictor } & \text { edf } & \text { F-value } & \text { p-value } & \text { Partial } \mathrm{r}^{2}(\%) \\ \text { SSB } & 1.71 & 33.1 & <0.001^{* * * *} & 52.7 \\ \text { N1 } & 1.00 & 19.8 & <0.001^{* * *} & 18.2 \\ \text { SST } & 1.00 & 10.0 & 0.004^{* *} & 11.3 \\ \text { C. finmarchicus } & 1.25 & 4.53 & 0.031^{*} & 6.5 \\ \text { T.longocornis } & 1.00 & 5.89 & 0.023^{*} & 5.7\end{array}$

* edf is the estimated degrees of freedom for the model smooth terms where edf $>1$ indicates a nonlinear relationship. The partial $r^{2}$ refer to the percentage of the total deviance explained by each covariate separately. 


\title{
FIGURES CAPTIONS
}

Figure 1. Long-term trends in (a) sandeel recruitment (grey bars), spawning stock biomass (SSB; black line) and (b) mean fishing mortalities (F at ages 1-2; grey) estimated from stock assessments (ICES 2017). Horizontal dotted lines represent the precautionary and limiting stock sizes $\left(\mathrm{B}_{\mathrm{pa}}\right.$ and $\left.\mathrm{B}_{\mathrm{lim}}\right)$. Abiotic and biotic conditions affecting are recruitment success and juvenile survival are represented by (c) mean sea surface temperatures (SST) and the abundance of $C$. finmarhicus and $T$. longicornis at the Dogger Bank in spring (April-June) (d).

Figure 2. The partial effects of final model predictors on sandeel recruitment success with $95 \%$ confidence intervals (grey), illustrating negative relationships between log-recruitment success and spawning stock biomass (SSB) (a), the number of one-year old sandeel (b) and spring sea surface temperature (c), as well as positive effects of prey abundance during spring by C. finmarchicus (d) and T. longicornis (e).

\author{
Figure 3. (a) Observed (circles) and fitted values (black) of recruitment success with $95 \%$ \\ confidence intervals (grey) based on the final GAM. (b) Observed (circles) and hindcasted estimates \\ of spawning stock biomass (SSB; black) with 95\% confidence intervals (grey) based on an age- \\ structured population model.
}

Figure 4. (a) Boxplots of explained deviance from a cross-validation analysis of model fit on a randomly selected subset, as well as the associated accuracy of predictions on the remaining data (after 1000 model iterations). (b) Overall explained deviance (grey) and p-values of the effects of 
SSB (solid), abundance at age 1 (dashed) and temperature (dotted) on sandeel recruitment success when successively fitting and annually updating the final model on data from 1997 to 2015. (The horizontal gray dashed line indicate significance at $\mathrm{p}=0.05$ ).

Figure 5. (a) Hindcast simulations of sandeel SSB based on: (i) observed SST, C. finmarchicus, $T$. longicornis and F values (black); (ii) reduced F to current levels (2010-2015) (black dashed); (iii) reduced SST to mean levels during the 1980s (black dotted); (iv) introduced peaks in $C$.

finmarchicus in 1998, 2001, 2004 and 2007 (grey solid); (v) and all changes (ii-iv) together (grey dashed). The solid horizontal red line marks the limiting stock level ( $\left.\mathrm{B}_{\text {lim }}\right)$. (b) Probability of SSB falling below $\mathrm{B}_{\text {lim }}$ given changes in mean SST (by -1 to $2^{\circ} \mathrm{C}$ ) and fishing, given by a scaling factor on mean fishing mortalities-at-age (F multiplier) ranging from 0 to 2 , hence representing a fishing closure and doubling of mean F, respectively (where 1 represent $\mathrm{F}$ equal to the long-term average, $\left.\mathrm{F}_{\text {age } 1-2}=0.71\right)$ 

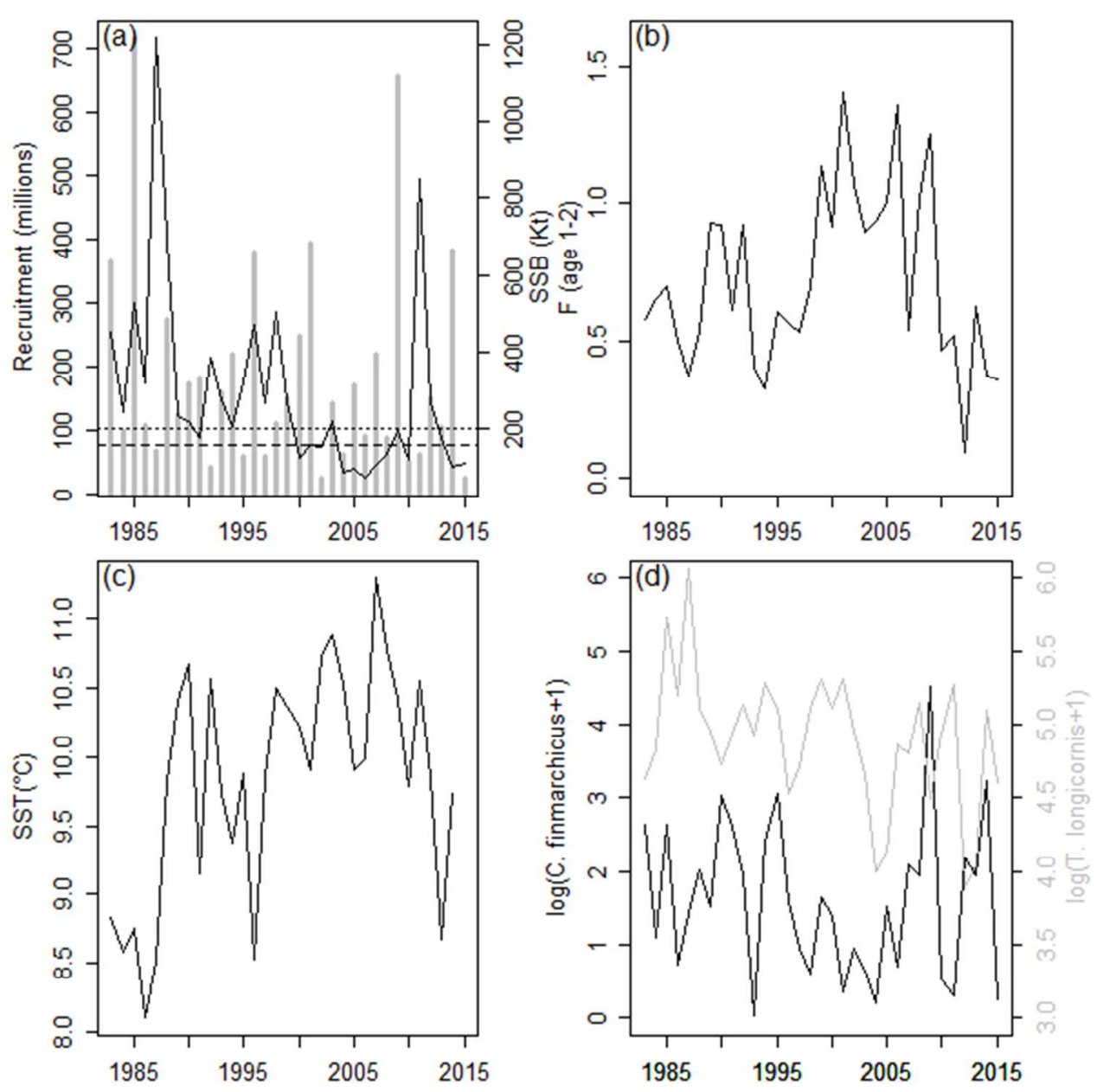

Figure 1

$218 \times 209 \mathrm{~mm}(72 \times 72$ DPI $)$ 

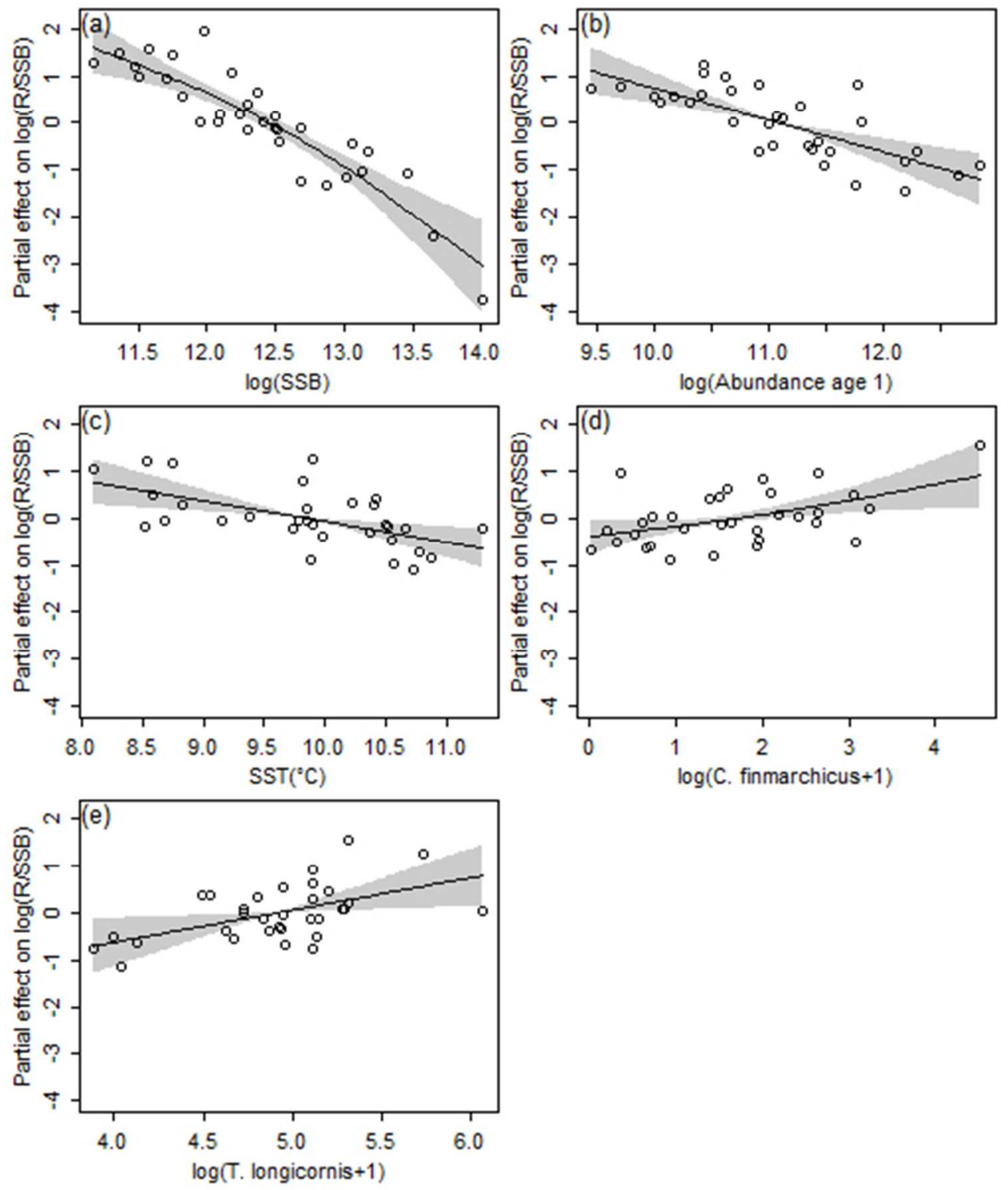

Figure 2

$185 \times 212 \mathrm{~mm}(72 \times 72$ DPI $)$ 

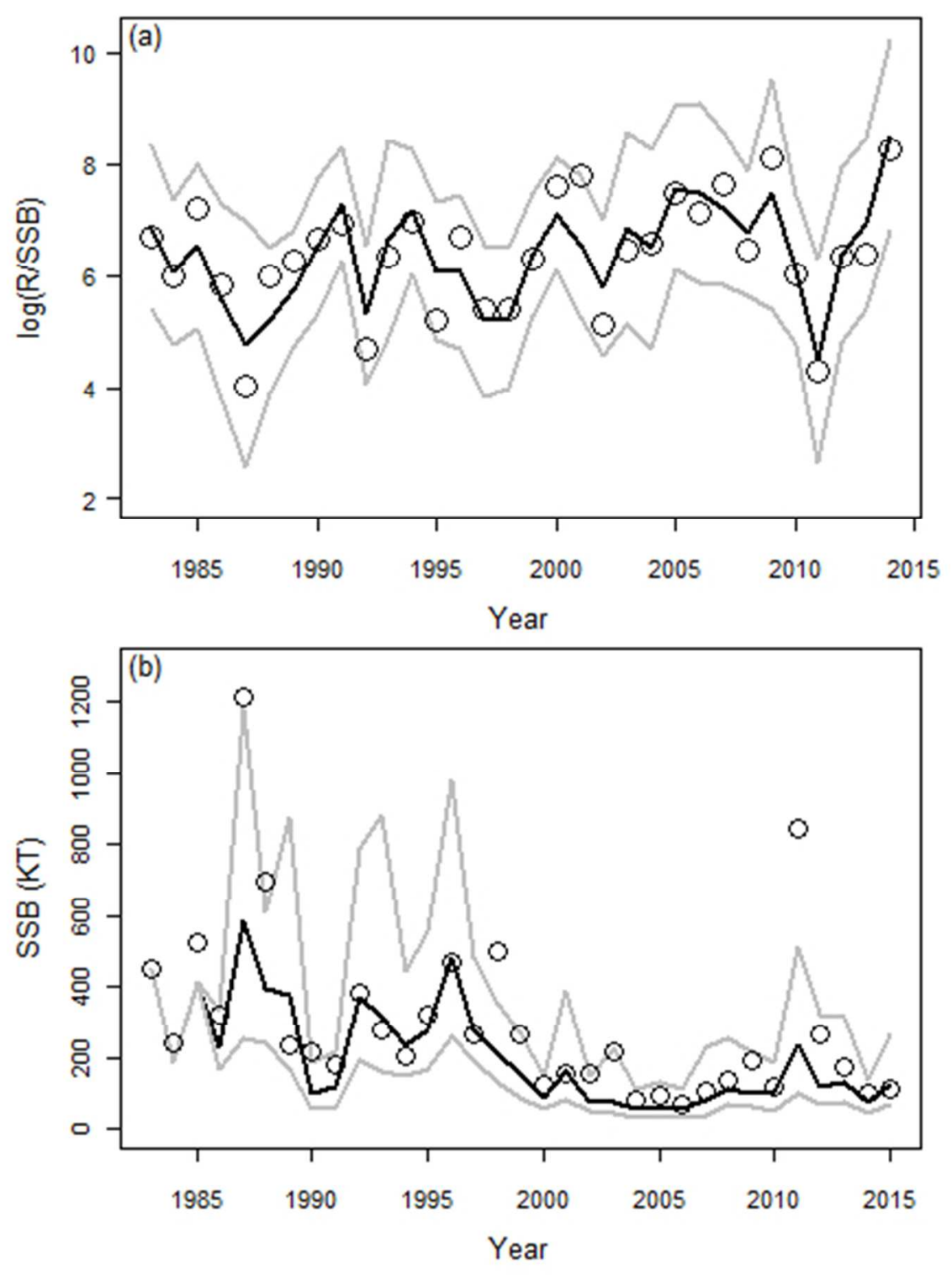

Figure 3 $161 \times 203 \mathrm{~mm}(72 \times 72$ DPI $)$ 

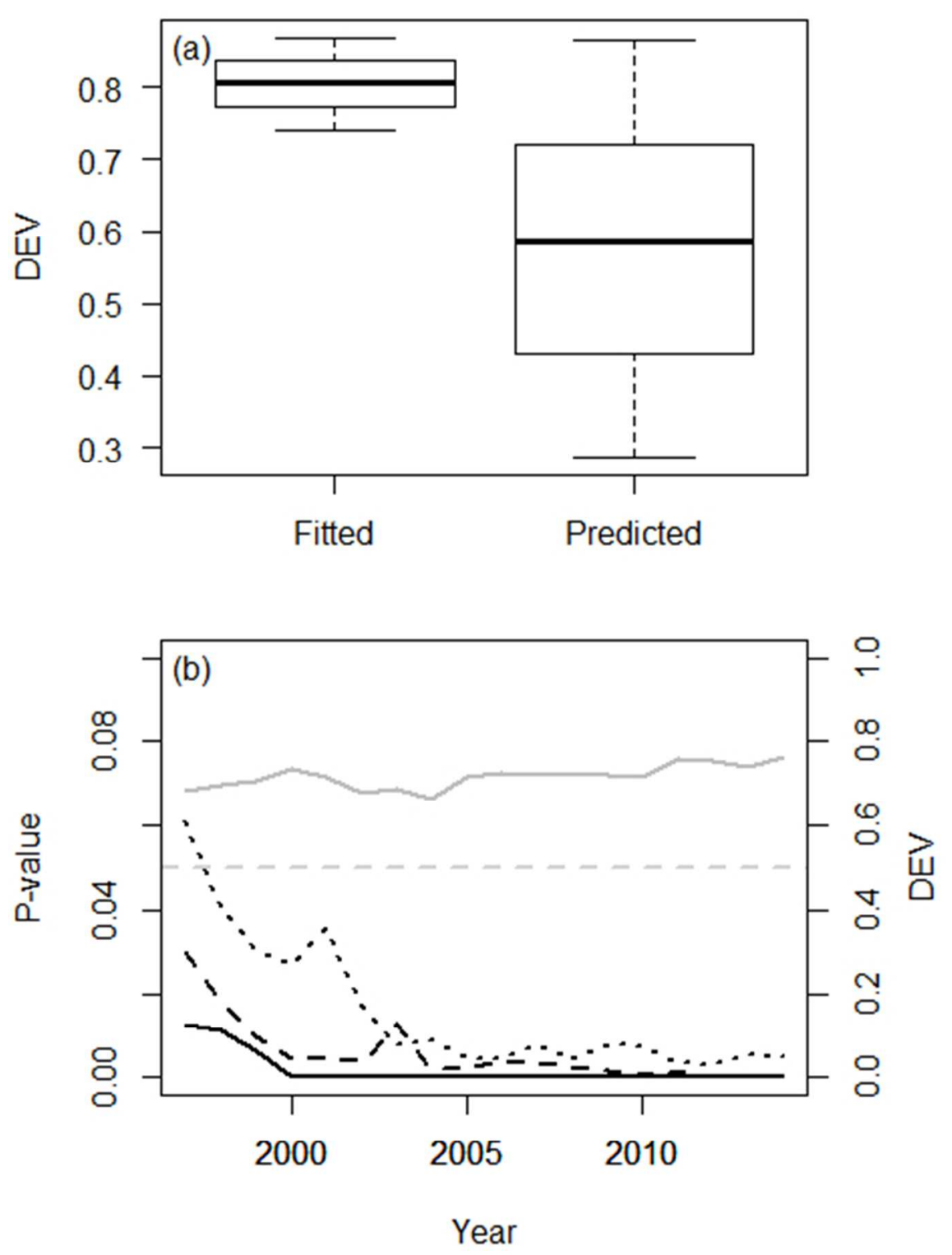

Figure 4 $187 \times 217 \mathrm{~mm}(72 \times 72 \mathrm{DPI})$ 


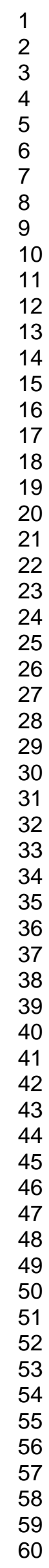

Figure 5

254×190mm (96 × 96 DPI) 


\section{SUPPLEMENTARY TABLES}

Table S1. The generalized cross validation scores (GCV) and Akaike's Information Criterion (AIC) after fitting the S-R model to each abiotic covariate and the zooplankton variables (Calanus

finmarchicus and Temora longicornis) in the corresponding quarter (or as annual averages). The selected model is highlighted in bold.

$\begin{array}{lll}\text { Variable } & \text { GCV } & \text { AIC } \\ \text { SSTQ1* } & 0.380 & 62.6 \\ \text { SSTQ2 } & \mathbf{0 . 4 1 1} & \mathbf{6 6 . 7} \\ \text { SSTQ3 } & 0.532 & 74.8 \\ \text { SSTQ4 } & 0.732 & 85.8 \\ \text { SSTAnnual } & 0.443 & 69.5 \\ \text { SBTAnnual } & 0.456 & 70.1 \\ \text { NAOAnnual } & 0.475 & 71.5\end{array}$

*Note that fitting the model on SST and zooplankton in quarter 1 yielded the lowest AIC/GCV. However, the model showed a spurious and ecologically unrealistic negative effect of prey availability (Temora longicornis) on recruitment success (Fig. S2) and was therefore excluded. 
Table S2. Summary of three alternative model parametric model formulations. Extended Ricker

$\ln (R / S)=c_{1} S+c_{2} \ln (N)+c_{3} T+c_{4} Z_{1}+c_{5} Z_{2}+k\left(\right.$ (M 1), simple linear regression $R=c_{1} S+c_{2} N+c_{3} T+c_{4} Z_{1}+c_{5} Z_{2}+k$ (M 2), and second order polynomium $\ln (R / S)=c_{1} \ln (S)+c_{2} \ln (S)^{2}+c_{3} \ln (N)+c_{4} \ln (N)^{2}+c_{5} T+c_{6} Z_{1}+c_{7} Z_{2}+k$ (M 3$)$.

The models use the same input as the GAM model in the main text of this manuscript: R (recruitment, in thousands individuals), $\mathrm{S}$ (spawning stock biomass, in tons), $\mathrm{N}$ (number of age-1 sandeel, in thousands individuals), $\mathrm{T}$ (sea surface temperature in ${ }^{\circ} \mathrm{C}$ ), $\mathrm{Z}_{1}(\mathrm{CPR}$ index for Calanus finmarchicus), and $\mathrm{Z}_{2}$ (CPR index for Temora longicornis). See material and method and Table 1 in the main text for a more detailed description of data sources. The table contains estimated coefficients $\left(\mathrm{c}_{1}-\mathrm{c}_{7}\right.$ and $k$ ) and the associated p-values (presented within parentheses, alpha $=0.05$ ).

Estimated coefficients:

\begin{tabular}{lccccccccc}
\hline Model & c1 & c2 & c3 & c4 & c5 & c6 & c7 & K & 15.43 \\
M1 & -0.0000046 & -0.72 & -0.42 & -0.22 & -0.83 & & 0.69 & 421500000 \\
M2 & -230.5 & -843 & -74150000 & 6.356 & 110800000 & 0.36 & 0.22 & 0.74 & -44.45 \\
M3 & 9.46 & -0.44 & 1.16 & -0.085 & -0.47 & 0.22 & 0.71 \\
\hline
\end{tabular}

P-values for each coefficient:

\begin{tabular}{lcccccccc}
\hline Model & $c 1$ & $c 2$ & $c 3$ & $c 4$ & $c 5$ & $c 6$ & $c 7$ & K \\
\hline M1 & $<0.001^{* * *}$ & $<0.001^{* * *}$ & $<0.01^{* *}$ & $0.042^{*}$ & $0.01^{*}$ & & $<0.001$ \\
M2 & 0.112 & $0.025^{*}$ & $0.041^{*}$ & $0.017^{*}$ & 0.1 & & 0.334 \\
M3 & 0.084 & $0.047^{*}$ & 0.725 & 0.569 & $<0.01^{* *}$ & 0.072 & $0.018^{*}$ & 0.298 \\
\hline
\end{tabular}




\section{SUPPLEMENTARY FIGURES}

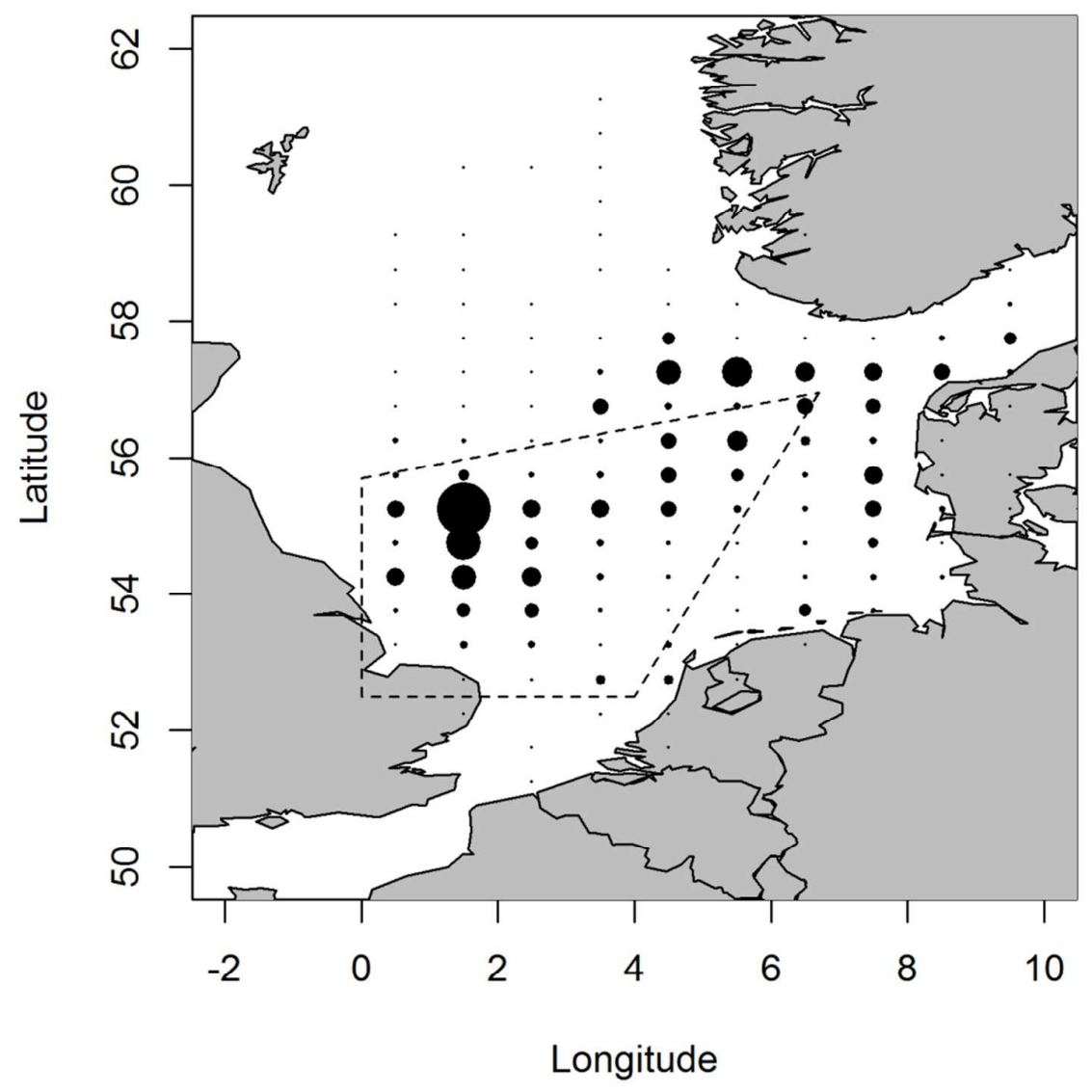

Figure S1. Map of the study area. Black round symbols illustrate the relative distributions of sandeel landings since 2003. Box with dashed boundaries envelopes Dogger bank and all landings from sandeel management area 1 (the Dogger bank population). 

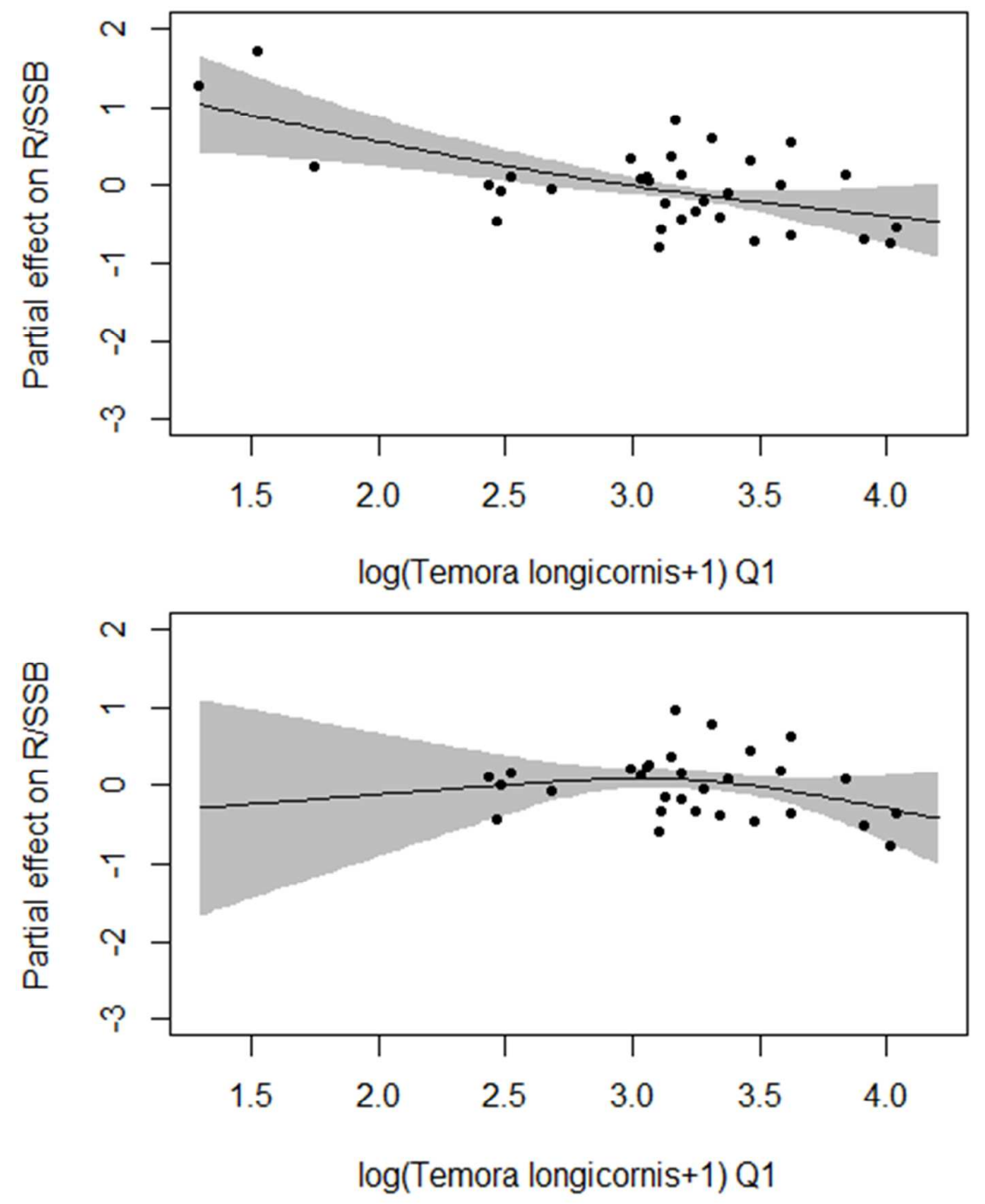

Figure S2. The partial effect of Temora longicornis in quarter 1 on sandeel recruitment success.

The model shows a spurious and ecologically unrealistic negative effect of prey availability (upper panel) which is entirely driven by three observations with low zooplankton abundances. If excluding these during fitting the relationship becomes insignificant $(\mathrm{p}=0.49)$ (lower panel). 

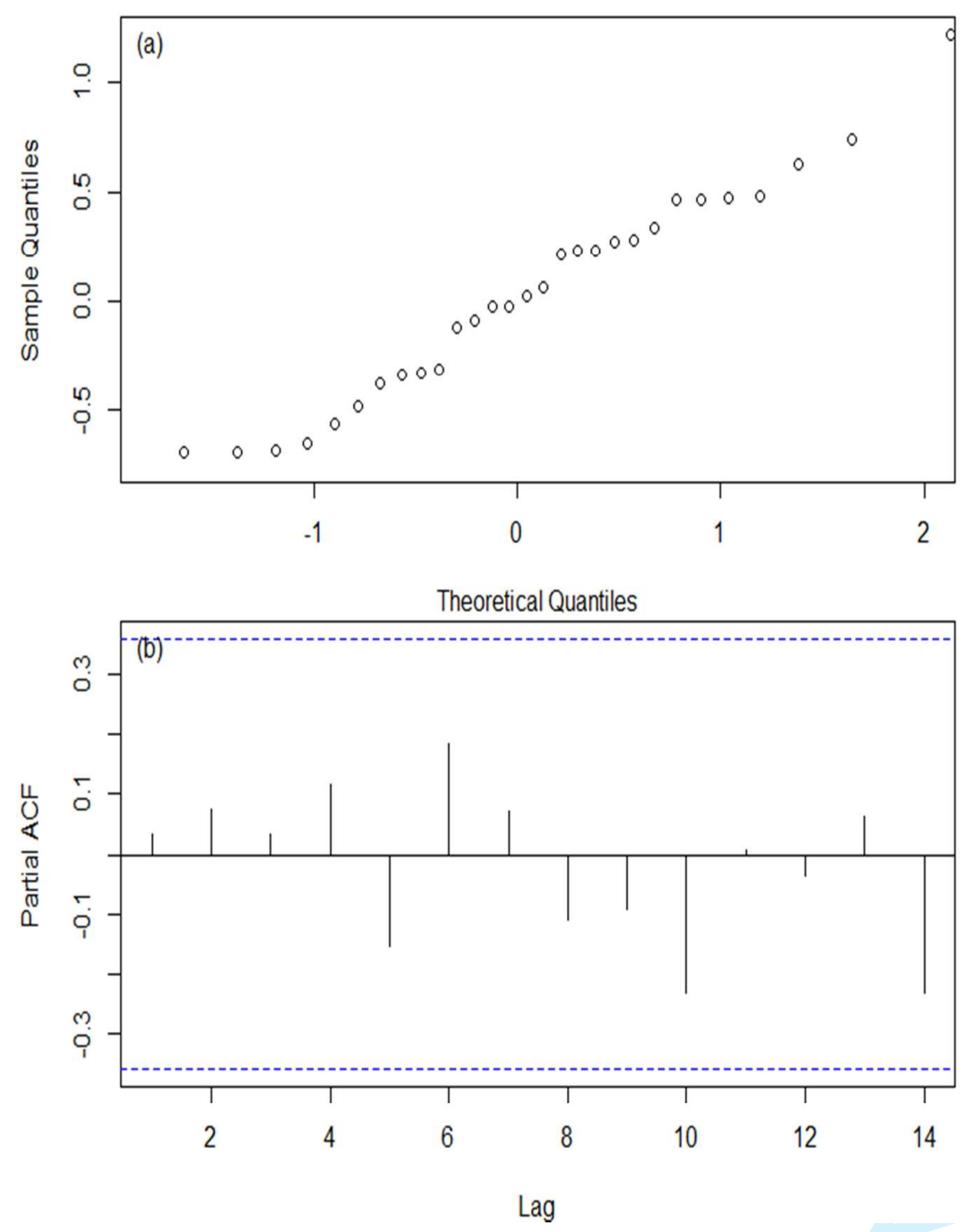

Figure S3. (A) Normal probability plots and (B) partial autocorrelation plots of the final S-R models for sandeel recruitment success. 